\title{
JUDAÍSMO: ANTIGO E MODERNO. OBSERVÂNCIA MAJORITÁRIAAO DIREITO TALMÚDICO. DIREITOS HUMANOS
}

\author{
JUDAISM: ANCIENT AND MODERN. MAJORITY OBSERVANCE TO THE TALMUDIC LAW.
}

HUMAN RIGHTS

Antonio Augusto Machado de Campos Neto*

"Le bonheur n'est pas chose aisée: il est très difficile de le trouver en nous, et impossible de le trouver ailleurs"

[A felicidade não é coisa fácil: é muito difícil encontrá-la em nós, e impossivel encontrá-la alhures]

Nicolas de Chamfort

"Nós, judeus, acreditamos que a missão divina da qual fomos incumbidos constitui a própria razão da nossa existência. E tal missão não é se empenhar para que outros povos se tornem judeus, mas, sim, empenhar-se para que todos os povos do Mundo, independentemente de suas respectivas crenças, reconheçam a soberania de Deus e aceitem os valores humanos que nos foram revelados por Ele. O dever de um judeu não é fazer um Mundo mais judaico. O dever é fazer um Mundo mais humano"

Rabino Henry I. Sobel (em entrevista ao jornalista Claudio Blanc)

"O homem chega ao Mundo com as mãos fechadas, como se dissesse: este Mundo é meu... O homem deixa o Mundo com as mãos abertas, como dizendo: vejam, não levo nada comigo"

Passagem do Talmude, o Livro hebraico

"O buraco negro do Universo, talvez nem seja negro; mas pulsa como o coração"

Stephen Hawking

\footnotetext{
Bacharel em Direito pela Faculdade de Direito da Universidade de São Paulo. Jornalista pela Faculdade de Comunicação Social Cásper Líbero. Ex-Editor e Ex-Chefe do Serviço Técnico de Imprensa e Propaganda da FDUSP.
} 


\title{
Resumo:
}

Em premissa maior, o Judaísmo não envolve somente rituais, conhecimentos religiosos ou cerimoniais. A função é a de extrema compreensão na conduta de um sistema de vida em qualquer circunstância e situação de vida aos seus seguidores. A sua doutrina implica estudos da Thorah, o Livro das Leis judaicas, o qual estabelece minuciosamente as ações corretas a se realizar, enfatizando a crença de que a Fé é conquistada por intermédio dessas ações, extraídas da própria vontade encontrada no âmago do Espírito de cada indivíduo. O conjunto do Judaísmo está descrito nas Sagradas Escrituras; Livros que compõem a Bíblia Sagrada no "Velho Testamento", divididos em três partes, a saber: a Lei (Thorah), os Profetas (Nebi'im) e os Escritos Sapienciais ou Hagiógrafos (Ketubin). Cumpre salientar que Thorah tem o significado original de instrução divina transmitida a um profeta ou sacerdote escolhidos, individualmente, pelo Criador-de-Todas-as-Coisas, tornandose herança imbatível do Povo judeu: verdadeiro guia de vida; todavia, ensinamentos consistentes de preceitos, a palavra Thorah é invariavelmente traduzida como Lei. Por último, Thorah tem a denominação de Pentateuco, composta de cinco Livros, a saber: Gênesis, Êxodo, Levítico, Números e Deuteronômio e nela estão registrados os primeiros períodos da História de Israel, desde a libertação dos israelitas por Moisés da escravidão no Egito. A Thorah, segundo os rabinos, possui 613 preceitos, 248 mandamentos e 365 proibições, cujo conteúdo teria sido escrito por Moisés até 1225 a.C. Algumas Nações nasceram para brilhar - caso de Israel -, uma vez não se tratar de uma história qualquer, incluindo o legado deixado à Humanidade, por meio do Judaísmo - antigo e moderno -, perpetuado por um Povo, escolhido pelo Deus Único - os israelitas -, que eternamente deve ser narrada e repassada aos futuros homens deste pequeno e incrível planeta ... a nossa Casa! Premissa final: Talmude significa ensinamentos; trata-se de compilação literária, redigida em hebraico e aramaico que, por sua vez, reúne debates e discussões dos antigos rabinos acerca de vasta gama de questões religiosas e sociais, existindo em duas versões: Talmude Babilônico e Talmude Palestino, cuja observância é regida em tempos atuais do sistema jurídico israelense e pedra fundamental do Judaísmo rabínico, a exemplo dos Direitos Humanos, muito avançados na Israel moderna.

Palavras-chave: Resumo sucinto do Judaísmo antigo e moderno. Direito Talmúdico. Diásporas romana, oriental, sefardita e asquenaze. Direitos Humanos. Israel moderna.

\begin{abstract}
:
In the main premise, Judaism does not only involve rituals, religious or ceremonial knowledge. The function is one of extreme understanding in the conduct of a life system in any circumstance and situation of life for its followers. Its doctrine implies studies of the Thorah, the Book of Jewish Laws, which establishes in detail the correct actions to be carried out, emphasizing the belief that the Faith is conquered through these actions, extracted from the very will found in the heart of the Spirit of each one. individual. The whole of Judaism is described in the Holy Scriptures; Books that make up the Holy Bible in the "Old Testament", divided into three parts, namely: the Law (Thorah), the Prophets (Nebi'im) and the Sapiential Writings or Hagiographers (Ketubin). It should be noted that Thorah has the original meaning of divine instruction transmitted to a prophet or priest chosen, individually, by the Creator-of-All-Things, becoming an unbeatable heritage of the Jewish People:
\end{abstract}


true guide of life; however, consistent teachings of precepts, the word Thorah is invariably translated as Law. Finally, Thorah has the denomination of Pentateuch, composed of five Books, namely: Genesis, Exodus, Leviticus, Numbers and Deuteronomy and the first periods are recorded in it. of Israel's history, from Moses' liberation of the Israelites from slavery in Egypt. The Thorah, according to the rabbis, has 613 precepts, 248 commandments and 365 prohibitions, the content of which would have been written by Moses until 1225 BC Some nations were born to shine - the case of Israel -, since it is not just any story, including the legacy left to Humanity, through Judaism - ancient and modern -, perpetuated by a People, chosen by the One God - the Israelites -, who must forever be narrated and passed on to the future men of this small and incredible planet ... our House ! Final premise: Talmud means teachings; it is a literary compilation, written in Hebrew and Aramaic which, in turn, gathers debates and discussions of the ancient rabbis about a wide range of religious and social issues, existing in two versions: Babylonian Talmud and Palestinian Talmud, whose observance is governed in current times of the Israeli legal system and a cornerstone of rabbinic Judaism, like Human Rights, very advanced in modern Israel.

Keywords: Concise summary of ancient and modern Judaism. Talmudic Law. Roman, Eastern, Sephardic and Ashkenazic diasporas. Human Rights. Modern Israel.

\section{Judaísmo antigo \\ 1. Introdução}

Comprovado cientificamente, o Oriente Médio fora o berço do Povo judeu, mais precisamente o "Crescente Fértil" traçado em arco, desde a porta do Golfo Pérsico até o Vale do Eufrates e na direção Sul através da Síria e da Palestina, atingindo o Egito. A Região contém as áreas mais antigas de povoações judias que se conhece e é o marco dos fatos que dominam a crônica tradicional das origens judaicas. Geograficamente, consiste principalmente em terra fértil cultivada, rodeada de montanhas e desertos. Historicamente, fora o lugar em que se estabeleceram impérios poderosos, cuja vicissitude proporcionara o substrato de boa parte da narrativa bíblica, condensada na Bíblia hebraica. Os judeus da Antiguidade acreditavam que sua história - mesclada à Humanidade -, havia se iniciada na Mesopotâmia; mas, também, consideravam o Egito, na outra extremidade do Crescente, como elemento importante na constituição de sua origem. Por último, acreditava-se que Abraão, considerado o pai do Povo judeu, fosse originário de Ur, perto do Golfo Pérsico como, também, tivesse vivido durante algum tempo em Haran, Norte da terra de Aarão, antes de ele viajar na direção Sudoeste até a Palestina e o Egito. A sua sepultura fora localizada em Hebron, perto de Jerusalém e pode ser visitada na modernidade, contemplando a História da Humanidade.

Moisés “o legislador” nasceu no Egito; porém, adulto, levou seu Povo ao deserto na preparação à entrada da Terra Prometida, fatos amplamente conhecidos 
pelos estudiosos. A Bíblia hebraica descreve a origem do Povo judeu em tempos de história coerente que se desdobra desde os deslocamentos da família de Abraão através do cativeiro egípcio ao Êxodo, de vida nômade ou seminômade à existência sedentária e de uma organização essencialmente tribal à organização nacional. Enfim, após período de anarquia marcado pela liderança militar de juízes - que se diziam juízes - se estabelece dois Reinos, a saber: Judá, no Sul e Israel, ao Norte. Daí em diante, falta de comprovação, mas descobertas arqueológicas apoiam a história da conquista de Canaã, lento processo que abrangeu todo o século XIII a.C. As narrativas bíblicas atuais são marcadas por reelaborações editoriais posteriores às tradições antigas; algumas, podem ter conservado crônicas autênticas. Pesquisas intensas apontam que ainda não está comprovado como surgiram as doze tribos ou, precisamente, como e quando se uniram em uma só Nação. Os nomes das tribos estão relacionados a determinadas Regiões do território e ainda que as divisões tribais refletissem originalmente estreitos vínculos de sangue; o que em seu momento determinou a identidade tribal foi o do critério mais geográfico em parâmetro ao genealógico, dando mais significância às unidades menores à família e ao clã, bem como à identidade nacional.

Durante o período da Monarquia, o domínio tribal era maioria simbólica, dando passagem às novas realidades de administração centralizada e estilo de vida predominantemente agrário e urbano. A Monarquia marcou o encorajamento de desenvolvimento de nova classe mercantil participante do comércio internacional e local. Embora comprovação escassa, alguns comerciantes se estabeleceram temporariamente em parte do Exterior até então conhecido, lançando alicerces da posterior diáspora mercantil, uma vez a Bíblia hebraica registrar a concessão de um bairro comercial na cidade de Damasco em 860 a.C., época do Rei Ahab (Reis: 20-34). E na conquista do Reino do Norte pelos assírios, final do século VIII, a incipiente diáspora começou a adquirir importância maior. O Reino sulista de Judá continuou a sua jornada, vivendo à sombra dos assírios e durante certo período, final do século VII, enquanto a Assíria se defendia dos assaltos dos medos e dos babilônios, o Rei Josias restaura a Lei judaica em parte do território que, em época anterior, tinha sido governado pelo Rei David. Advém a invasão da Babilônia e grande contingente de judeus deportada às terras babilônicas; outros fugiram para o Egito. Os exilados mantiveram a Fé de retorno, quando o Rei Ciro, o Grande, da Pérsia conquista a Babilônia, em 539, permitindo que os judeus voltassem à Jerusalém ... e a reconstruísse debaixo de muito sacrifício braçal.

Nem babilônios nem persas interferiram no âmbito social e religioso interno das comunidades judaicas, na jornada da vida, pela Babilônia dos persas, classificada como a mais bela cidade da Antiguidade. Os judeus viveram ali muito tempo e alguns preferiram se estabelecer definitivamente, uma vez conquista de cargos adquiridos por mérito, enfatizando o profeta Daniel, exemplo mais narrado e comprovado, incluso ter 
deixado série de documentos de papiro, extremamente conservados na biblioteca da Corte babilônica. Quanto aos judeus que seguiram para viver no Egito, tinham o próprio templo em Elefantina, ainda que aparentemente não houvesse nenhum interesse ou tentativa em construí-lo, durante a permanência babilônica. Dentre eles, grupos dos que exigiam a obediência extrema às normas jurídicas da Lei judaica. Essas comunidades conservavam a identidade baseada em passado, fortalecida por meio da lealdade familiar e do clã, sendo que a ideia de Nação não estava associada diretamente ao território: a Lei de Deus, que se estendia a toda a terra, ainda que sua morada estivesse de forma especial em Jerusalém; daí a expressão secular "Jerusalém é passado, presente e futuro". Em 331 a.C. os macedônios conquistaram a Pérsia, liderados por Alexandre III, o Grande, filho do Rei Filipe, assassinado brutalmente com a conivência de sua mulher. Alexandre - qualificado como um dos mais belos homens em passagem neste planeta - e sucessores não alteraram a situação de seus súditos judeus que continuaram o desfrute em igualdade de tratamento e limitado autogoverno. Os judeus eram incentivados a se estabelecerem em cidades recém-fundadas; nesse período - primeiros anos do domínio macedônio registra-se expansão massiva, por todo o Mundo grego, da diáspora, enfatizando o território Oeste, pela Ásia Menor e Egito. As comunidades judaicas eram organizadas em corporações oficialmente reconhecidas ("politeumata"), governadas por líderes e conselhos com seus próprios tribunais que, por sua vez, administravam a Lei judaica tradicional. Outras comunidades minoritárias também tinham suas politeumatas em cidades gregas; todavia, em muitos requisitos, o caso dos judeus não podia ser qualificado de excepcional. Porém sua liberdade para viver sob suas próprias Leis implicava certos privilégios, como o da isenção de cultuar deuses pagãos ou a de render honras divinas aos governantes, assim como a da liberdade de observar o descanso sabático. [Aliás, esses episódios se sucederam em conflitos desde a época dos profetas Elias e o seu substituto Eliseu, século IX a.C. em Samaria, protagonizados entre o profeta Elias, o Rei Akhab e a princesa pagã fenícia Jezabel; o motivo: a invasão e pretensa conquista do Exército da Fenícia, na tentativa da implantação do Paganismo, afrontando a Rainha Aisha, mulher do Rei, o Exército israelita e as Leis judaicas - usos e costumes judaicos -, liderado pelo general Bharszulai, exemplo de homem e exímio defensor de Israel].

Enfim, esses privilégios que não deixavam de ser especiais eram condição fundamental para a vida judaica como, também, requisito essencial para que governantes pudessem contar com a lealdade dos judeus. Isso constituía fonte de satisfação para os judeus e frequentemente de ressentimento aos vizinhos não judeus. Por outro lado, a situação no território de Judá - chamado Judeia pelos greco-romanos - e de sua capital Jerusalém era diferente, porque ali os judeus constituíam a maioria da população, inclusive continuidade de boa proporção ao desempenho de autogoverno, nos mesmos moldes anteriores sob o domínio persa. Todavia, o governo em Jerusalém estava em mãos dos 
sumos sacerdotes hereditários e de conselhos da cidade à maneira grega. Era permitido a eles administrar o território, sob as Leis ancestrais e aplicá-las aos cidadãos não judeus.

Nesse período, a Judeia era parte do Reino ptolomaico e depois, 200 a.C., do Reino selêucida havendo pouca interferência na autonomia judaica até o Reinado de Antíoco; este depôs o sumo sacerdote Onias, vendendo o cargo ao seu irmão, Jasão. Por sua vez, Jasão aboliu a tradicional "teocracia” e constituiu em Jerusalém uma polis grega com o nome de Antioquia de Jerusalém; época de inesperada guerra civil durante a qual Antíoco tomou Jerusalém, em 169 a.C. Em seguida, o próprio Antíoco instala ali legião de soldados sírios e sancionando a introdução da adoração pagã no Templo, em 167 a.C. Todavia, continua a resistência sob a liderança de Judas Macabeu que, por sua vez, alcança notável sucesso militar e diplomático, incluso cumprimento do código legislativo mais amenizado, cujo resultado foi o do estabelecimento da família de Judá, os Hasmoneus, como Dinastia reinante em uma Judeia independente. Jônathan, irmão de Judas Macabeu, foi reconhecido sumo sacerdote e governador local pelo Rei; sendo seu sucessor outro irmão, Simão, após a sua morte, em 142 a.C., o qual conseguiu a independência, sob a condição de imunidade do tributo à Síria. Em assembleia pública a proclamação formal de Simão como líder nacional (etnarca) e sumo sacerdote: o mais importante mandato perpétuo, significado de que o seu cargo era doravante hereditário. De fato, seu filho João Hircano (135-104 a.C.) o sucedeu; e a este, seus filhos Aristóbulo (104-103 a.C.) e Alexandre Janeu (103-76 a.C.). A partir daí, o domínio judaico se expandiu a todos os territórios conquistados, cuja população era forçada ao Judaísmo e as cidades resistentes eram totalmente aniquiladas. O nome Judeia se estendeu a todo o território e os governantes, a partir de Aristóbulo, ostentaram o título real assim como demais outros governantes da Região, helenizados.

À morte de Alexandre Janeu, sua viúva Salomé Alexandra governou como Rainha de 76 a 67 a.C. O seu filho mais velho/primogênito Hircano era o sumo sacerdote e consequentemente após a morte da Rainha, trava-se uma guerra entre Hircano e o seu único irmão Aristóbulo Júnior, dando margem ao fim da independência judaica, motivada pelo general romano Pompeu - comprometido com a vitoriosa campanha na Ásia Menor e na Síria - que interveio na guerra civil, após batalha de três meses de duração, quando conquista Jerusalém, em 63 a.C. A cena do general romano invadindo junto ao estado maior o Sancta Sanctorum do Templo, lugar sagrado e reservado exclusivamente ao sumo sacerdote, deixou impressão marcante, chocante e duradoura em mentes judaicas. O escritor Josefo relata sucintamente o ocorrido:

Perdemos nossa liberdade e nos transformamos em súditos dos romanos. Tivemos de devolver aos sírios os territórios conquistados e, além disso, os romanos nos cobraram em breve período 1.000 talentos. E o Reino que antes havia sido 
dado aos sumos sacerdotes, por herança, foi devolvido aos laicos.

\section{O domínio romano}

Cerca de 700 anos seguintes o território foi governado pelos romanos que, em geral, aceitavam os judeus como governantes dos clãs da Região como, também, consentiam administrarem os próprios assuntos sociais e jurídicos particulares; todavia, eram os romanos que efetuavam ou ratificavam, oficialmente, as nomeações necessárias e requisitadas. Em períodos de tensão, não hesitavam recorrer à força, muitas vezes violenta, no intuito da manutenção da paz romana. Nos mesmos moldes da ação brutal dos fenícios, em Samaria, que prendiam ou eliminavam os profetas israelitas.

Devido disposições do general Pompeu, o território da Judeia se tornou reduzido, sob a supervisão do governador da Síria. Hircano se estabeleceu sumo sacerdote, porém não conseguiu manter seu título real. Em seguida, Júlio César o nomeou etnarca, em 47 a.C., e o poder estava nas mãos de Antípatro de Sídon, o primeiro general da governança de Hircano. Mister se faz recordar que este período foi marcado por muitas lutas, a maioria provocada por Aristóbulo Júnior e seus filhos, os quais pretendiam a conquista do trono. E durante anos, de 40-37 a.C., Antígono, um dos filhos, governou efetivamente como o Rei de Jerusalém, obtendo apoio efusivo dos partos que haviam conquistado a Região. A sequência vem com Herodes, filho de Antípatro, reconhecido como Rei pelo Senado romano, em 40 a.C., reconquistando o território com o auxílio do Exército imperial, governando até a sua morte no ano 4 a.C.

Por meio de Herodes, o sumo sacerdócio se torna completamente reduzido a pouco mais do que função cerimonial e submetida à autoridade do Rei. O Sinédrio, conselho supremo judaico, foi privado de poder político e substituído por novo conselho real. Embora de nacionalidade judaica, Herodes governou extenso território da numerosa população não judaica e tentou combinar os papéis de Rei judeu com a de governador heleno. O seu Reino foi bem-sucedido e próspero, embora marcado de espantoso desprezo pela vida de quem o rodeava, incluso os membros de sua família. Dentre os seus planos arquitetônicos, inclui-se a reconstrução do Templo de Jerusalém em estilo helênico, assim como diversos outros palácios, acrescentado de importante Porto em Cesareia. Ele é classificado como o último dos grandes Reis judeus e em muitos aspectos de seu Reinado, reporta-se ao de seu legendário predecessor: David.

Herodes nunca deixou de considerar que o seu poder dependia dos romanos e o seu desempenho como Rei era o de executar a política romana na Região governada por ele. À morte de Herodes, o Reino se torna dividido entre os três de seus filhos. Nenhum deles ostentava o título de Rei; mas, esse arranjo político não foi satisfatório e 
tampouco permanente. Nesta trajetória, a Judeia foi administrada por série de governantes classificados de categoria "equestre", excetuando breve interlúdio, em 41-44, no qual governou como Rei o neto de Herodes: Agripa. Um dos governantes se casou com a filha de Agripa, tornando-se cunhado do Rei. Por último, o terceiro, judeu, nascido em Alexandria. Nenhum deles tinha conexão real com o Judaísmo. Todavia, existia grande rejeição, por parte da população judaica. A dominação romana era perceptível como ocupação militar e exploração fiscal. Os sumos sacerdotes e o conselho, em Jerusalém, não tinham poder efetivo, destacando-se que as relações entre gregos e judeus eram péssimas. Os fatos eram corriqueiros, ocorrendo diversos movimentos revolucionários, além de cotidianos confrontos, irritando os membros da Guarda Nacional romana que agiam com brutalidade, na busca de apaziguar a Região.

Em 66, rebelião latente explode com o assassinato do sumo sacerdote, luta brutal e selvagem entre judeus e gregos nas cidades periféricas e mistas. O Exército romano necessitou de quase oito anos para sufocar a comoção; em parte pela insegurança política que se produziu em Roma, após o suicídio do imperador Nero, em 68; porém, mais que nada pela decidida resistência dos rebeldes judeus. Os romanos tomaram Jerusalém no ano 70 e incendiaram o Templo, incluso as suas bases: o último bastião rebelde, Massala, foi destruído em 74. A guerra marcou o fim de Jerusalém como a capital judaica e a extinção das instituições fundamentais do antigo Governo teocrático: o Templo, o sumo sacerdócio e o Sinédrio. Porém, os romanos não tentaram abolir a Religião judaica junto ao Governo; ao contrário, permitiram a instalação de novo Conselho constituído por sábios em parâmetro aos sacerdotes ou autocratas. O novo corpo ocupou-se com a reorganização e administração interna dos judeus e a Província torna-se devidamente independente da Síria, sob a autoridade de governadores de categoria senatorial. Em 132, deflagra segunda revolta, comandada por Simão bar Kosiba, se autointitulando nasi (etnarca) de Israel. A insurreição durou três anos e meio, custando aos romanos grandes perdas ... mas custou muito mais aos judeus. Um número elevado deles, incluso membros mais destacados da nova liderança, foi morto, vendido como escravo ou desterrado. Todos os sobreviventes foram para o exílio e Jerusalém, novamente, fundada como cidade romana com o nome de Aelia Capitolina, detentora de considerável território ao seu redor. A Província perdeu o nome judaico e recebe o de Syria Palestina por seus antigos habitantes: os filisteus ... origem do nome Palestina!

O Povo judeu torna-se minoria em todas as partes da Região, exceto na Galiléia, repleta de refugiados. Durante breve período, o Governo toma a medida, excepcional, de proibir a circuncisão, a educação e ordenação rabínicas, no intuito exclusivo de exterminar o Judaísmo. O propósito foi rapidamente abandonado, surgindo nova política que restaura um autogoverno judaico limitado, sob um etnarca hereditário ou nasi que presidia um conselho de sábios e administrava a Lei tradicional, por meio de uma 
rede de tribunais judeus. Os etnarcas acumulavam consideráveis fortunas e privilégios; contavam, ainda, com uma Corte de estilo régio, mesmo porque se proclamavam descendentes do Rei David; todavia, possuíam força oficial/policial própria e, por último, frota invejável de navios, no intuito do transporte de seus produtos fabricados por meio dos mares. A política de apoio ao etnarca junto à nomeação de governadores de alto escalão e da manutenção de um Exército poderoso na Palestina tem o efeito desejado de assegurar a paz. Tanto assim que, de 135 a 351, não ocorreu revolta judaica e durante o transcorrer do ano 351, na tentativa de restaurar o Reino, sob o comando de um judeu chamado Patrício, o etnarca permaneceu fiel a Roma. Revoltas posteriores, talvez atribuíveis ao período da primeira Legislação antijudaica de imperadores cristãos foram acontecidas com veemência. A partir daí, a posição dos judeus no Império romano gradativamente se deteriorou com o interlúdio excepcional do imperador Juliano, que era pagão, o qual tentou reconstruir o Templo em Jerusalém no ano 363; porém, a tentativa foi frustrada devido a terremoto violento na Região da cidade e pela morte do imperador, logo em seguida. Todavia, talvez tenha sido o mesmo Juliano imperador quem conferiu ao etnarca o alto status honorifico de prefeito pretoriano aos futuros imperadores. Mais tarde, no ano 415, o imperador Teodósio II cancela esta honraria e uma Lei, de 429, aborda o fim do patriarcado, demonstrando que Teodósio II se limitara a não reconhecer como sucessor o último patriarca: o cargo é extinto.

Quanto à Palestina, se encontrava dividida em três Províncias, das quais somente duas áreas possuíam população judaica considerável; áreas que tinham os seus próprios conselhos judaicos independentes: Tiberíades e Cesareia. Os judeus da Palestina como os da diáspora romana resistiam à política de cristianização e às vezes se opunham pela força; porém, não ocorreram enfrentamentos graves a não ser em 613, quando judeus ficaram ao lado dos persas, na conquista da Palestina. Jerusalém caiu em 614 e durante alguns anos até 617 se restabeleceu a dominação judaica junto ao culto sacrifical e no mesmo ano a cidade foi invadida e conquistada novamente pelos romanos, quando judeus foram expulsos pela segunda vez. No entanto, pouco tempo depois, o país foi conquistado pelos árabes, pondo término ao domínio romano.

3. A diáspora romana, oriental e asquenaze. O período medieval

3.1. No ano 70, desde a destruição do Templo de Jerusalém, não houve diferenciação entre judeus da Judeia e os das demais Regiões do Império romano. Todavia, a diáspora romana continuou a se expandir, em parte motivada pelo proselitismo, ainda que tenha havido algum movimento do Judaísmo para o Cristianismo ou, ainda, para a Religião do Estado. Segundo historiadores e cientistas religiosos é difícil dispor de números precisos ou exatos, mas se pode calcular que antes do ano 70 viviam cerca 
de 2 milhões e meio de judeus na Judeia e muito mais de 4 milhões na diáspora romana; sobretudo, posteriormente, depois da revolta de 132-135, a proporção da diáspora, com relação ao povo judeu-palestino, cresceu consideravelmente. E é provável que os judeus representassem algo em torno de um décimo da população total do Império romano; nos lugares de maior concentração, as cidades das Províncias orientais podem ter atingido a constituir 1/4 da população. Recorda-se que, mais tarde, os romanos se tornam provedores de um Exército imponente e de política extremamente desenvolvida, conquistando mais de cinquenta Províncias na Europa, na África, governando por séculos essa vastidão. E não se olvida a Eterna Roma, erguida ao torno entre sete colinas, contemplando o início da ascensão da civilização deste Mundo. O perfil da política romana era a de reconhecer os direitos existentes dos judeus, além de manter o máximo possível do status quo. Por outro lado, os problemas que poderiam surgir se resolvia antecipadamente, segundo critérios locais e não se tentava formular princípios fundamentais a todos os judeus, conforme acontecido mais tarde em governos cristãos. A condição legal e os direitos civis judaicos variavam em consonância ao lugar como, também, segundo os cidadãos, dentro da mesma comunidade; nelas, gregos compartilhavam a vida social; todavia, em constantes atritos havendo a necessidade da interferência romana no intuito de apaziguá-los, conforme já detalhado. O sucesso da política pragmática romana foi notável e os poucos casos em que falhou - como os distúrbios anteriores às revoltas na Judeia - nas lutas entre judeus e gregos que se estenderam até o Egito e Chipre e demonstrando, também, quão violentas e sangrentas eram as comoções que Roma deveria manter controladas.

Embora os judeus se sentissem pertencentes a uma Nação nas conhecidas tentativas de resolver intervenção alheia em seus conflitos ou orquestração de rebelião generalizada, incidentes se reduziam a uma Região ou cidade. Por outro lado, os romanos reconheciam os fatores que congregavam judeus em um só corpo social, sobretudo o da Religião. Ainda que não autorizassem a Religião judaica de maneira explícita, tolerância existia na prática, junto aos reconhecidos antigos privilégios. O envio de doações das Províncias ao Templo de Jerusalém era permitido e quando destruído, as contribuições regulares foram destinadas ao Tesouro romano imperial, em forma de impostos. Enfim, a política fiscal revelava reconhecimento dos judeus, ainda que disperso por todo o Império. Se a carga tributária e a desonra de tal discriminação irritassem os judeus, eles se encontravam compensados pela proteção da pax romana e honras dispensadas aos etnarcas ou representantes da Nação judaica. Além de ser proibida a circuncisão dos não judeus e sua instalação em Jerusalém não havia para os judeus outras restrições, exceto pelas que eles mesmos quisessem impor. 


\subsection{A diáspora oriental}

Além das fronteiras do Império romano, existiam inúmeras comunidades importantes, a exemplo de antigos centros da Babilônia e Mesopotâmia; algumas, inclusive, de história continuada desde a remota Antiguidade até os dias atuais. Todavia, ao decaírem as antigas povoações - como a própria Babilônia -, as novas cidades e suas indústrias mercantis atraíram habitantes judeus e alguns deslocamentos em grande escala devido a guerras e deportações. O território de povoação judaica era extremamente vasto, organizado desde a Armênia até a Arábia, no Sul; e a Média e Elam, atingindo Meri, no Leste, aonde se estenderam, por meio das principais rotas comerciais. As povoações mais significativas se encontravam na Babilônia; todavia, ali constituíram somente uma comunidade entre as várias minorias étnicas religiosas. Registra-se que os partos dominaram parte da Região, desde o final do século II a.C. até o início do século III d.C., havendo pouca interferência na vida dos seus súditos. Em curto período, a Babilônia foi governada por um judeu chamado Asineu, entre 20 e 35 d.C. e com o apoio do Rei parto. Judeus na Palestina continuaram a espera que a Pártia os reportasse da dominação romana e não devem ser excluídas razões de ordem nacionalista para se explicar a lealdade deles aos partos, ainda que as vantajosas condições de que desfrutavam, sob o governo deles, pareçam motivo suficiente. E é provado pelos historiadores de que judeus orientais tentaram se emancipar da liderança judaica palestina; além do que os partos reconheceram ou tenham instituído um etnarca judeu: o Resh Galutha ou "chefe do exílio", análogo ao da Palestina. Os poderes e dignidade de tal cargo nada tinham de inferiores e chegavam a ser classificados como superiores aos dos etnarcas romanos (etnarca, do grego=governante da Nação), parecendo ter sido criado à competição do governador romano. Um dos muitos principados tributários dos Reis partos, Adiabene, foi governado em pouco tempo por judeus. Neste período a Rainha Helena e seu filho Izates se converteram ao Judaísmo, início do século I d.C. A família construiu grandes monumentos em Jerusalém e significativo apoio sem reservas aos rebeldes na guerra de 66-74, sendo os únicos judeus estrangeiros que o fizeram. Todavia, não se pode justificar se estavam respaldando a política parta e a absoluta falta da resposta dos judeus da Babilônia. Outra família governante em Hismiar, no Iêmen, também se converteu por um tempo ao Judaísmo no final do século IV e, novamente, no início do século VI, apoiando com significância a comunidade judaica, embora em breve período.

Com relação aos persas sassânidas, sucessores dos partos, 224 d.C., as condições continuaram a ser totalmente favoráveis aos judeus, embora, periodicamente, os governantes tentarem lhes impor a Religião persa: o Zoroastrismo, lembrando, também, de que eles sofreram grandes perdas em guerras. O cargo de chefe do exílio se manteve; incluso rigoroso reforço. À medida que a posição dos judeus na Roma cristã 
gradativamente se deteriorava, eles se sentiram atraídos pelos centros mais prósperos e livres do Oriente. No início do século V, registra-se ataque religioso contra judeus e cristãos. As lendas judaicas acerca do breve estabelecimento de um Estado independente em Mahoza, no final do século $\mathrm{V}$, podem estar relacionadas com essas perseguições; todavia, crônicas são fantásticas e pouco confiáveis. Talvez o exílio tenha sido abolido durante esses distúrbios que podem ter sido restaurados no século VI. Mas o último século e meio de dominação sassânida é lembrado como "período difícil e obscuro" e os judeus ofereceram calorosa acolhida aos árabes que tomaram o Oriente Médio, no ano de 630.

\subsection{A diáspora sefardita}

Em 1492, foram expulsos da Espanha um considerável número de judeus, um marco na vida judaica, sendo este país o último Estado cristão, onde viveram habitantes adeptos do Judaísmo; em média, de 200 a 250 mil sem se computar os convertidos, ressalvando que muitos tinham um grau de prosperidade elevada. A expulsão havia sido decretada durante a recém-capturada Alhambra de Granada, em 30 de março daquele ano. Em 30 de julho de 1492, todos os judeus haviam aceitado o batismo ou partiram para o exílio. Cerca de 100 mil optaram pela solução mais viável: fugir para Portugal; aliás, decisão equivocada, porque cinco anos depois, pressionados pela Espanha, o Estado português batizou à força todos eles, sem exceção, em meio a cenas extremamente violentas. Por outro lado, a Itália recebe parte dos exilados espanhóis mediante condições políticas, acarretando situação desapropriada desses refugiados: humilhados e fustigados. Uma parte do Sul da Itália, Sicília, com antiga e numerosa população judaica pertencia ao domínio espanhol; portanto, sujeitos ao decreto de expulsão como, também, outras Regiões que se encontravam com o mesmo problema de ordem internacional e a contrarreforma, ao Norte, aumenta a hostilidade. A esperança aos refugiados estava completamente fora do universo cristão, quando alguns foram contemplados ou compensados a se estabelecerem em definitivo no Marrocos ou, ainda, em Regiões do Norte africano como a capital Tunis, Tunísia. Um século antes muitos refugiados já haviam escolhido o Norte da África para fugir das perseguições cristãs. A população muçulmana em nada era amistosa, acrescentada das regras de segregação que se tornaram reforçadas; mas, o Império otomano acolhe bem os refugiados, quando o rabino de Creta, Elias Capsalis, junto à sua família oferece hospitalidade a alguns fugitivos de passagem por Candia. Ele se sentiu inspirado a compor a crônica elogiosa otomana narrando que os turcos zombavam do Rei da Espanha. Mesmo porque otomanos não tinham preconceitos cristãos ou islâmicos e os espanhóis - intitulados sefarditas devido ao nome bíblico da Espanha, Sefarad obtiveram favores especiais, uma vez importarem ofícios úteis, conhecimentos técnicos, matemáticos e medicinais, principalmente os da área oftalmológica, sendo pioneiros no 
início do tratamento da anomalia ocular, a catarata, além de habilidade comercial e política. Territorialmente, eles se estabeleceram em todas as grandes cidades, reconstruindo ruínas de vidas e culturas devastadas. A cidade de Salônica se torna um lugar essencialmente judeu e desenvolvimento avançado de um Porto comercial classificado como o mais importante do Mar Mediterrâneo: uma glória judaica.

Em 1517, Egito e Palestina caíram sob o domínio otomano e uma atração à imigração judaica, embora os sefarditas, por meio do idioma e cultura espanhola, dominassem as comunidades judaicas do Império não impedindo a entrada de novos refugiados de outros países. Alguns, em condições de retribuir a acolhida recebida, prestavam serviços extraordinários ao Estado otomano como Joseph Nasi, duque de Naxos (1515-1579) e Salomão Aben-Ayish, duque de Mitilene (1520-1603), ambos de Portugal e o italiano Salomão Asquenaze (1520-1603) computados entre os mais destacados diplomatas de sua época, exercendo, todos os três, influência em questão de nível internacional. Lembra-se que emigrados portugueses eram cristãos convertidos que, por sua vez, renunciavam ao Cristianismo ao aportarem em terras livres. A intenção era a de escapar de centros judaicos mais importantes. Recentemente, devem a sua origem a grupos cristãos novos portugueses, em cuja lista são incluídos os de Londres, Amsterdã, Hamburgo e Nova York.

\subsection{A diáspora asquenaze e o período medieval}

Asquenaze, de Ashkenaz, é nome bíblico (Gênese: 10-3) identificado por meio da Alemanha; judeus de origem alemã ou polonesa. No hebreu medieval, a Alemanha era conhecida com o nome Ashkenaz, período das expulsões e perseguições, as quais não conseguiram extinguir, por completo, a vida judaica; todavia, as condições materiais e culturais tornam-se péssimas. Excluídos das cidades, os judeus optaram pela dispersão em direção a pequenas vilas e aldeias, existindo constante corrente de emigração rumo ao Leste, ou seja, à bela e atual Polônia, lugar onde foram atraídos, desde o século XIII, motivados pela concessão de privilégios especiais. Esta corrente se torna mais forte durante as agitações da Reforma. Imigrantes asquenazes, na Polônia, foram tão numerosos como os sefarditas na Turquia, compondo idioma e cultura religiosa aos judeus nativos, desempenharam importante perfil econômico como classe média alta entre a aristocracia feudal e os camponeses e o controle do comércio interno e externo. Recorda-se que nem o ódio de classe nem a intolerância religiosa ameaçaram a segurança, compartilhando prosperidade e riqueza do Renascimento polonês dos séculos XVI e XVII. Mediante cooperação dos governantes, desenvolveram forte administração estatal interna, único na diáspora e o denominado Conselho das Quatro Terras - composto pela grande e pequena Polônia, Podolia e Volhynia; Lituânia (contava com o seu próprio conselho) - exercia 
amplos poderes; quase parlamentares! A idade dourada da comunidade judaica polonesa, assemelhada a da comunidade de Amsterdã, na época marcante do comércio dos bulbos da bela flor, as tulipas, terminou brusca e violenta durante a rebelião cossaca, de 1648 . Entre os objetivos do líder, Bogdam Chmielnicki, apontava a erradicação do Judaísmo na Ucrânia. A tristeza é a de que centenas de judeus assassinados, batizados à força ou obrigados novamente a fugir. Não havia respaldo jurídico internacional, tampouco Direitos Humanos a evitar tamanha ação desumana! Historiadores judeus relatam que mais de 100 mil foram mortos e trezentas comunidades destruídas, sendo que os massacres deixaram profunda ferida na alma da comunidade judaica polonesa e a imagem dos devastadores cossacos aterroriza alguns judeus asquenazes nos dias atuais, introduzindo na Mitologia judaica com a mesma categoria das Cruzadas ou a da expulsão violenta da Espanha. Os massacres de Chmielnicki foram apenas a primeira eclosão de violência que se abateria periodicamente sobre os judeus até a culminação no Holocausto nazista.

[Holocausto (do grego "oferenda queimada totalmente"). Termo que, originalmente, designava "sacrificio que ofogo consome inteiramente" é empregado hoje para se referir ao massacre de cerca de 6 milhões de judeus executados pelos nazistas e seus colaboradores].

A Polônia não permaneceu sem judeus; pelo contrário, a população polonesa continuou espetacularmente crescente, de modo que em meados do século XIX, compunha a metade da população mundial; mas a diáspora asquenaze se torna característica permanente e dominante, dentro do cômputo do Judaísmo internacional. Na Alemanha, a situação se tornara mais estável, embora judeus estivessem excluídos de muitos lugares e de alguns Estados menores, começaram a admiti-los. Durante a Guerra dos Trinta Anos (1618-1648), judeus foram autorizados a residir em grandes cidades e a tendência anterior de dispersão no campo rural iniciou a se inverter. A premissa maior é a de que a guerra ofereceu oportunidade ao enriquecimento dos pequenos comerciantes, relacionados com o Exército, por meio de fornecimento de armas até o início do século XVIII: uma ocupação tipicamente judaica em toda a Europa. Judeus cortesãos "hofjuden" do final do século XVII e início do século XVIII eram imensamente ricos e poderosos, reunindo a sua volta vastos círculos de judeus que, gradativamente, foram assimilados pela cultura dominante. Enquanto isso, comunidades alemãs cresciam com a imigração e luxuoso estilo de vida dos judeus cortesãos, contrastando com a pobreza e a aglomeração dos judenejassen. Enfim, a diáspora asquenaze se estendeu aos poucos para o Leste europeu e meados do século XVIII havia cerca de 20 mil judeus na Alsácia; alguns menos na Inglaterra e, estranhamente, muito mais em Amsterdã, cuja comunidade judaica havia sido durante um século a mais numerosa na Europa Ocidental. Época da vida privada, quanto ao ofício, de joalheiros e importadores de riquíssimas joias; continuaram a se expressar em iídiche até o século XIX, mesmo porque o idioma comum facilitava a integração de novos 
contingentes, no intuito de maior contato com outras comunidades asquenazes como, também, tendência em distingui-los dos sefarditas. Nas Regiões mediterrâneas, sefarditas assimilavam as minorias asquenazes, nos centros do Norte europeu, Amsterdã e Londres, onde asquenazes constituíam imensa maioria, existindo pouca fusão entre os dois grupos.

Por último, os casamentos entre os distintos grupos não eram permitidos, enfatizando sefarditas, imbuídos de sentido de cultura superior, além de sentimentos de pureza racial, originados nos difíceis anos vividos na Península ibérica-cristã; mantinham sinagogas e organizações comunais separadas; mas logo chega o momento dessas barreiras serem derrubadas, cujas diferenças ocasionaram animosidade real; todavia, descendentes dos dois grupos seguiram experimentando apego emocional às suas respectivas tradições!

\section{O Judaísmo no Mundo Moderno. Direito Talmúdico. Direitos Humanos 1. A liderança da comunidade judaica}

Em breve preâmbulo, o período medieval da História judaica se caracteriza pela segregação compulsória dos judeus pelos não judeus. $\mathrm{O}$ caso mais extremista é o simbolizado pela barreira física das paredes do gueto; todavia, até mesmo onde havia muros físicos, um muro invisível existia, separando, assim, dois muros diferentes, porque os judeus não se encontravam separados dos não judeus apenas pela Religião como, também, pela situação política e sistema legalizado; pelas estruturas sociais e econômicas de suas comunidades, pela cultura intelectual e ainda pelo ritmo de vida cotidiano. Recorda-se que a liderança da comunidade judaica se encontrava em rédeas do rabinado: a classe mais letrada que se autoperpetuava como exímia fiadora da cultura religiosa tradicional. Os rabinos desfrutavam de considerável independência, incluso a relação junto de seus pares; como juízes e autoridades religiosas, exerciam poder efetivo, geralmente com o consentimento e apoio dos governantes não judeus, os quais deixavam para os judeus excelente margem de autonomia judicial e autogoverno. Mister salientar que houve rebeliões contra a autoridade rabínica; todavia, raras e quase nunca chegaram a se instituir mobilizada, dada fraqueza oposicionista; incluso o Movimento Caraíta que constituiu o desafio mais coerente e de sucesso maior contra o rabinismo, desenvolvendo o próprio estilo do rabinado. Os rabinos podiam esgrimir poderosa sanção, cherem, espécie de excomunhão que, por sua vez, excluía à vítima desempenho à vida econômica, religiosa e social da comunidade; punição que para um judeu - fora da comunidade - não havia mais sentido em viver, uma vez a sanção classificada como arma eficaz.

No século XIX, cristãos recorreram à Teologia no intuito de justificar o status quo; os judeus eram mantidos subjugados como testemunho de seu pecado ao rejeitar Jesus Cristo e para que acreditassem em sua segunda vinda. Os massacres e expulsões eram justificados pela doutrina do pecado do Povo judeu. Mas desde o 
início do século XVII, Baruch Spinoza, em Amsterdã, estabelecia base de uma Filosofia Universalista que limitava estritamente a validade da Legislação divina ocorrida tanto entre os judeus quanto os cristãos. Um judeu imbuído da tradição humanista ocidental, Manasseh Ben Israel, enfatiza a esperança de Israel, explorando argumentos messiânicos em sua campanha bem-sucedida pela readmissão dos judeus na Inglaterra, tendo como um de seus resultados a precursora Carta sobre a tolerância, de John Locke, em 1689. Cem anos depois, 1789, a integração dos judeus na sociedade europeia era amplamente propiciada pelos pensadores mais esclarecidos daquele período. Entre 1789 e 1781, oito anos antes, C.W. Dohm publicou influente tratado intitulado Sobre o progresso civil dos judeus e um ano mais tarde, 1782, Moisés Mendelsohn em sua Introdução à reivindicação dos judeus, de Manasseh Ben Israel, associava a melhoria das condições dos judeus ao progresso humano em geral, um dos pioneiros documentos ao acervo dos Direitos Humanos. Dois anos depois, 1784, publica seu seminário intitulado Jerusalém, no qual advoga pela separação entre a Igreja e o Estado.

Em 1785, a questão judaica era uma das preocupações dos pensadores do Iluminismo, mas a proeminência que atingiu esta época revela consciência crescente de que a segregação e a subordinação se tratavam de uma enfermidade da sociedade europeia. A celebração aconteceu em Metz, em certame sobre a maneira de se conseguir com que judeus franceses fossem mais felizes. Para maioria dos filósofos pensadores, a situação se reportava à injustiça, obrigatoriamente combatida e banida da sociedade em razão dos Direitos Humanos: garantia aos judeus em igualdade civil básica junto à tolerância e liberdade religiosa. Pensadores que tinham projetos contundentes e ambiciosos como a integração total, pondo, assim, o fim do domínio da Religião considerada supersticiosa até a conversão ao Cristianismo. Medidas coercitivas, cuja resposta dos judeus foi cautelosa e renegada. O que já se esperava por esta decisão.

No século XIX, reformas efetuadas em vários países europeus com alcance e objetivos variados, segundo a percepção do problema e condições legais. Nos EUA, revolucionários à posição dos judeus, como imigrantes e refugiados da repressão religiosa, mal os diferenciava de seus vizinhos. As ideias políticas do Iluminismo se situavam firmemente estabelecidas, propiciando ao Povo judeu condições ou status de solicitar não somente a simples "tolerância", mas a completa igualdade, em consonância aos princípios diretores da Revolução americana. Tanto assim que a Constituição de 1787 proibia explicitamente o questionamento religioso para a obtenção de cargo público, embora alguns Estados internos dos EUA a mantivessem e a Ata dos Direitos Civis, de 1791, garantia total à liberdade religiosa. A Revolução americana, portanto, inaugura nova Era da emancipação política à comunidade judaica; mas, em princípio, contempla alguns milhares de judeus, quando as últimas implicações foram amplas, graças à imigração em massa e à elevação gradual dos EUA, em posição dominante no dicionário 
da História Universal e o mais significativo: repercussão em quase todos os países. $\mathrm{O}$ episódio acontece aos mesmos moldes da França, quando a Revolução francesa extingue a segregação medieval do Povo judeu como tantos outros abusos contra os Direitos Humanos, salientando-se que a emancipação foi debatida repetidamente na Assembleia Nacional, uma vez haver forte resistência. Por último, em 1789, votação foi perdida por 403 votos contra 408: uma diferença de três votos!

A ansiedade e a paixão pela liberdade foram suficientes para que a questão fosse reconsiderada; sobretudo, depois que os próprios judeus apelassem à Assembleia a novo reconhecimento em votação de sua igualdade cívica; fato acontecido após a prisão do Rei Luís XII, em clima de equilíbrio de forças, mudando satisfatoriamente a permissão para que fosse aprovado em Decreto de Igualdade Política, 27 de setembro de 1791. Assim foi realizado com repercussão por toda a Europa. Na Holanda, por meio da Declaração da República da Batávia, 1795, proclama-se a igualdade de direitos, incluindo a liberdade religiosa, e a primeira Assembleia Nacional sanciona a Declaração de Igualdade ao Povo Judeu, em 1796. Na segunda Assembleia, 1797, são eleitos dois deputados judeus por Amsterdã e desde então judeus holandeses viveram em igualdade completa com seus concidadãos até a desastrosa ocupação nazista. Na Itália, os Exércitos da República, principalmente o romano, derrubam os muros dos guetos, arrancam emblemas das vestimentas judaicas e plantam "árvores da liberdade", em frente às sinagogas. Na Alemanha ocidental, guetos abolidos. Na Prússia, reformas constitucionais, de 1812, cidadania concedida, temporariamente, aos judeus. Na Inglaterra, a Revolução inglesa aconteceu bem antes, meados do século XVII, na concessão dos direitos aos judeus de liberdade às reuniões e à prática de eventos e culto. No final do século XVIII, judeus mais abastados encontravam-se muito bem integrados às classes altas da sociedade inglesa, embora a minoria dos nascidos no país não era classificada como cidadãos ingleses. Mesmo porque alguns imigrantes não adquiriram os direitos limitados de residentes, incluso aos que tinham cidadania compartilhada com diversos grupos não anglicanos; enfim, algum limite jurídico.

A questão da naturalidade foi resolvida em 1826 e o questionamento religioso abolido um século depois. Ressalva-se que estas reformas afetaram a minoria da comunidade religiosa judaica e muitas permaneceram "sem efeito", durante período de reação posterior à Batalha de Waterloo, 1815. Em 1871, a Constituição Imperial alemã incorpora o Princípio da Liberdade Religiosa em todo território europeu; mantiveramse à parte Suíça, Noruega, Espanha e Portugal. Por sua vez, a Europa Oriental se torna problema internacional isolado; todavia, na Rússia, onde vivia a metade da população judia mundial em condições absolutas de desigualdade, uma vez país desprovido de progresso econômico, técnico, educativo e social. Mas reformas do czar Alexandre II traz alívio inesperado com promessas de melhoria futura. 
A complexidade de respostas à pressão para a integração dos judeus se estende, inclusive a eles mesmos. A imagem-fotográfica emblemática dos judeus cambaleantes, entorpecidos pela luz da liberdade que os esperava fora das obscuridades do gueto, descreve de modo gráfico experiência frequente na Europa do século XIX. Mas alguns deles se adaptaram ao modus vivendi em outros países: havia judeus no Exército, governos, em profissões liberais e demais ocupação de ofícios, a exemplo do ramo das joalherias. Em 1806, Napoleão convoca assembleia composta de notáveis judeus, reafirmando irmandade entre franceses e judeus, oferecendo resposta evasiva à tolerância dos casamentos de judeus com cristãos: a Lei judaica não proíbe tais casamentos e o contraente judeu não deixa de ser judeu. Mas rabinos se opunham aos casamentos mistos, por não poder oficializá-los e casamentos com o perfil assinalado se tornaram comuns durante o século XIX, persistindo como foco de ansiedade em relação à observância da identidade judaica e aos limites da integração. A perseguição aos judeus era uma realidade, mas não logrou êxito duradouro incluso o de procedimento conjuntural, inclusive incorporado aos Direitos Humanos. Os precedentes de normas de Direitos Humanos radicam-se na tradição judaica, onde está a base da Rule of Law, do processo equitativo, de organização judiciária adequada, uma das primeiras preocupações de Moisés após a saída do Egito (Ex. 18, 12-27), da independência do magistrado. É devidamente conhecido que David dera asilo a um fugitivo egípcio que havia desertado de seu senhor. A aceitação de Raabi, natural de Jericó, e de seus pais e irmãos por autorização do conselho tribal liderado por Josué identifica precedente humanitário. Segundo Vicente Marotta Rangel, emérito professor desta Academia de Direito - honrado sou por ter sido aluno.

A consciência do dever de respeitar a pessoa humana está inexoravelmente vinculada a valores de ordem ética de que dão coerente e contínuo testemunho as páginas do Antigo e do Novo Testamento. Não se faz mister evocar que na essência do cristianismo se situa o postulado do respeito à dignidade humana.

E continua:

No Judaísmo, como esclarece Proper Weil, em curso da Academia de Direito Internacional de Haia, estão explicitados esses direitos e o dever de respeitá-los. A Bíblia não começa pela história do povo judeu mas pela da humanidade, cuja unidade fundamental se encontra assim posta conjuntamente em relevo. A Michna, parte do Talmude que recolheu, desde os primórdios, decisões jurídicas e comentários sobre textos bíblicos, dispõe que o homem foi criado sozinho 'para ensinar que quem atenta contra a vida de um só homem pratica ato grave como se houvesse destruído todo o gênero humano, enquanto que o que mantém em vida um só homem tem tanto mérito como 
se houvesse salvado todo o gênero humano'. 'Se o homem foi criado só, é ainda por outra razão', acrescenta o mesmo texto: 'a fim de que nenhum homem possa dizer a outro: meu ancestral é mais importante que o teu'. A condenação do racismo é nítida aí, por via de conseqüência. A unidade do gênero humano é também concebida em função do monoteísmo. Porventura não é um mesmo o pai de todos nós? Acaso não foi um mesmo Deus o que nos criou? pergunta o profeta Malaquias (Mal, 2,10). Pois a crença num só Deus concorre para o reconhecimento da unidade do gênero humano, a qual, aliás, não quer dizer uniformidade, pois está inserida entre as concepções básicas do judaísmo a noção de que embora seja um só o gênero humano, muitas podem ser as nações que nele se integram. (MAROTTA RANGEL, 1983, p. 236).

Nas lições de Marotta Rangel, apreende-se que em tempos atuais, a Organização das Nações Unidas não se limitou à tarefa de elaborar a Declaração Universal dos Direitos Humanos, de 1948, mas também tratou de completá-la, em 1966, com os Pactos Internacionais quer sobre Direitos Econômicos, Sociais e Culturais, quer sobre Direitos Civis e Políticos, assim como o Protocolo Facultativo referente ao segundo desses Pactos e no âmbito regional de nosso Continente, a Organização dos Estados Americanos (OEA) concorreu para a elaboração da Convenção de Costa Rica sobre Direitos Humanos, aprovada em 22 de novembro de 1969.

\section{A história judaica na Primeira Guerra Mundial}

Nos séculos XIX e XX, o Judaísmo iniciou processo de emancipação em trajetória terrível no âmbito político e social, advindo o surgimento de duas novas forças: antissemitismo e nacionalismo judaico. As duas forças comprometeram judeus contra não judeus como, também, judeus contra judeus, ocasionando em rápidas sucessões dois novos marcos históricos, ou seja, o Holocausto nazista e o estabelecimento do Estado de Israel. A década de 1880 - após as décadas 1860-1870 transformadas em incertezas - se inicia muito mal aos judeus centrados e radicados na Europa. Em 13 de março de 1881, o czar reformista Alexandre II é assassinado covardemente e em seis semanas mais tarde, cerca de um mês e meio, estoura uma onda de pogroms que se prolonga por um ano. Em mais de duzentas cidades turbas selvagens atacam judeus, matando, violando e saqueando suas propriedades debaixo de total impunidade e, aparentemente, com apoio oficial. Em maio de 1882, um programa de Legislação discriminatória, as Leis de Maio, anula as reformas recentes, impondo restrições intoleráveis à vida judaica e no mesmo ano um Congresso antissemita obtém cadeiras no Parlamento; e na Hungria reaparece a Certidão de Sangue, aos moldes da Idade Média! Premissa final: triste reflexão sobre a 
natureza humana, ou seja, a mesma que garantia a liberdade se revela em nova forma de hostilidade. Enquanto o antigo antijudaísmo cristão se justificava, mediante argumentos teológicos, o novo antissemitismo - termo sinistramente pseudocientífico, cunhado em 1879 - apelava para suposta inferioridade biológica e representava judeus como vírus estrangeiro, corruptor da sociedade europeia, demonstrando o Mundo daquela época: totalmente louco. $\mathrm{O}$ antissemitismo se alimentava de velhos preconceitos antijudaicos e a Igreja, por meio dos seus membros, que os havia criado e fomentado, nada fizeram para combater. Na Alemanha, o antessemitismo surge no âmbito do Partido Cristão Socialista fundado pelo pastor protestante Adolf Stöcker que, em 1882, presidiu o Congresso antissemita internacional de Dresden. Na Rússia, pogroms, de 1882, foram perseguidos em repetidas eclosões de terror, oficialmente apadrinhados; as Leis de Maio cumpridas com rigidez. Nesta combinação de violência e agressão legal, o começo de integração dos judeus na vida russa, brutalmente sufocada. E também surge novo rumo aos argumentos antissemitas, por meio da publicação de documento espúrio, cujo intuito a pretensão de plano judeu para a dominação mundial: os Protocolos dos Sábios do Sião, traduzidos em vários idiomas e distribuídos a todos os Estados europeus, incluso EUA e países da América do Sul. São Protocolos que até hoje caracterizam a propaganda antissemita, embora comprovada a décadas pelos cientistas, historiadores e jornalistas serem maliciosa falsificação. A partir daí, judeus aparecem como "presença estranha” como, também, movimento político subversivo.

O século XX se torna período de migração aos judeus; aliás, a toda Europa, uma vez grupos humanos deslocarem dentro do Continente e aos novos territórios que se abriam além-mar nas Américas, África do Sul e Oceania. A causa principal deste movimento: o total declínio europeu. A explosão demográfica judaica foi particularmente traumática, enfatizando-se as décadas 1800-1900, quando a população europeia duplicou, resultado da exímia administração advinda de Carlos Magno; todavia, a população judaica quadruplica, isto é, de 2,5 milhões para 10,6 milhões. O mais notável é o de que o grosso deste crescimento ocorreu na Europa Oriental, especificadamente na Rússia, atingindo de 1,6 milhão, em 1820, para 4 milhões, em 1880 e perto de 5,6 milhões, em 1910. Entre 1881 e 1914, cerca de 2,8 milhões de judeus abandonam a Europa Oriental: mais de $1 / 3$ da Região e mais de 1/4 da população judaica mundial. Esse semelhante movimento populacional não tinha precedentes na História judaica, mas notável efeito sobre o panorama do Universo judaico. Por último, os EUA surgem como a terra das oportunidades ilimitadas e da liberdade, atraindo imensa massa de imigrantes, principalmente europeus, sendo eles os primeiros povoadores que acompanharam a expansão do país, em direção ao Oeste e ao Sul, onde facilmente ganham a vida como comerciantes e artesãos. A afluência, a partir da Europa Ocidental, coincide com a da década de 1880, durante a crescente indústria norte-americana que, por sua vez, se originou pela colaboração imprescindível 
de imigrantes na cidade de Nova York, porto de entrada mais importante e em cidades avantajadas, onde os recém-chegados obtinham vínculos empregatícios como, por exemplo, mão de obra na indústria têxtil. O resultado: desenvolvimento de proletariado urbano judeu e óbvia consequência problemática de pobreza e insatisfação. Por volta de 1900, a população dos Estados Unidos havia atingido o cômputo de um milhão e, em 1914, a mais de 1,4 milhão. Em parâmetro atual, a cidade de Nova York sozinha, hoje, tem mais de 3,5 milhões de habitantes judeus, convertendo-a em larga margem na maior cidade judaica do Mundo! Na trajetória judaica, destaque ao barão Maurice Hirsch, fundador da Associação de Colonização Judaica (ICA), em 1891: o seu esforço foi o de aliviar a miséria judaica, inclusive disponibilizando fortunas do seu patrimônio pessoal. O seu plano era o de educar judeus russos, ensinando-lhes agricultura, proporcionando formação profissional; todavia, o Governo russo da época rejeitou a sua proposta, quando Hirsch se decidiu que a única solução dos judeus era o da imigração. A ICA teve o intuito não só de encarar os problemas de urgência da pobreza e da perseguição, por meio de imigração convenientemente organizada como, também, o da melhoria à vida judaica a longo prazo, estabelecendo colônias autossuficientes em territórios virgens de países livres, sendo a Argentina, particularmente, selecionada como especial à colonização agrária. Os membros da $I C A$ também ajudaram a fornecer subsídios ao Canadá, Brasil, à Palestina $^{1}$ e outros tantos lugares.

Quanto à Primeira Guerra Mundial, desastrosa a toda Europa - aos judeus prejuízo sem precedentes - a premissa final é a do número de baixas ocorridas em cômputo absurdo de mortes, ou seja, 140 mil, a maioria de origem russa e a observância de que pela primeira vez se desenvolveu em áreas densamente povoadas por judeus na Europa Oriental. Ressalta-se que, além de civis, durante a luta, muitos fugiram das zonas de guerra como refugiados; todavia, sucumbiram à fome e epidemias; e nos últimos momentos da guerra, estalaram pogroms na Hungria, Polônia e Ucrânia, em saldo de dezenas de milhares de judeus tanto mortos quanto sem lar. [No país húngaro, à margem direita do Rio Danúbio, dezenas de judeus enfileirados eram amarrados em corda e lançados às águas que banham Budapeste, a mais bela cidade da Europa; e, por esse ato desumano, monumento de pedras negras homenageia a crueldade]. Mas foram três grandes eventos ocorridos durante a Primeira Guerra Mundial que exerceram efeito significativo sobre

\footnotetext{
Obviamente, a Palestina foi um caso especial, uma vez que ali as oportunidades - tanto econômicas quanto políticas - não eram satisfatórias e os contingentes se dirigiram para lá em número reduzido, em parâmetro com o do fluxo que se dirigiu ao Canadá ou para a Argentina; tinham certo idealismo como motivação; todavia, frustrado frequentemente pelas condições pouco promissoras. Mas com o auxílio de benfeitores do Exterior e de organizações beneficentes, o número de imigrantes foi crescendo, quando várias colônias foram estabelecidas, atingindo 43, no ano de 1914.
} 
a História judaica, a saber: a Revolução russa, a conquista britânica da Palestina e o surgimento dos EUA na categoria de potência mundial.

A Revolução russa, março de 1917, varreu de um só golpe a Legislação opressiva antijudaica e mesmo quando os bolcheviques se apoderam do Poder, novembro daquele ano, não foi considerado na categoria de periculosidade, uma vez líderes dessa facção possuírem absoluta simpatia pelos judeus, vítimas proeminentes do Czarismo. Os bolcheviques não conseguiram eliminar o preconceito contra os judeus e por motivos ideológicos incorporaram a Religião judaica junto aos movimentos contrarrevolucionários do Bund e dos sionistas. Tanto assim que os judeus alcançam posições proeminentes no âmbito do Partido Comunista e do Governo russo. Já o avanço militar na Palestina coincide com o conhecimento oficial, por meio do Governo britânico das aspirações sionistas na Declaração Balfour, cujo objetivo maior de um lar nacional judeu foi incorporado junto ao Mandato da Liga das Nações para a Palestina, em 2 de novembro de 1917. Destacase que o término da dominação turca reforçou o nacionalismo no Oriente Próximo como, também, se enfatiza que a intervenção dos EUA na guerra europeia foi acompanhada e, de fato, precedida pela retomada de responsabilidade pelos judeus norte-americanos, em auxílio humano aos seus irmãos europeus: validade jurídica dos efeitos iniciais dos Direitos Humanos. Em 1906 nasce a fundação do Comitê Judaico-Americano com base no modelo de organizações europeias ocidentais como a Anglo Jewish Association e a Allience Israélite Universelle, no intuito de defesa dos direitos dos judeus em todo o Mundo, assim como o de amenizar as consequências da perseguição.

\section{As décadas 1920-1930}

Na década de 1920, o antissemitismo continuou, sendo grave empecilho social na Europa, sobretudo em Estados como Romênia, Polônia e Hungria, lugares esses imbuídos de cenários de política oficial, totalmente desfavorável aos judeus. $\mathrm{Na}$ Alemanha de Weimar, os judeus, pela primeira vez, desfrutam de total igualdade civil e política como, também, o Governo alemão reprime ultrajes aos judeus; todavia, partidos direitistas são ativos na difusão de propaganda ofensiva. E nos EUA é desatada onda de xenofobia, encontrando expressão significativa na polêmica antijudaica, na discriminação e na redução de cotas de imigração; este, o mais relevante. Lembra-se que a crise econômica, do final da década de 1920, intensificou o preconceito, ao mesmo tempo provocando séria discriminação nas verbas de auxílio humanitário: um prejuízo incomensurável. Nessa época, entre um terço e metade dos casamentos judeus eram celebrados com os não judeus, quando grande número de judeus abandona a comunidade que vivia, no intuito de conversão ao Cristianismo ou a se declararem não religiosos. Em seguida, poucos suspeitaram, pela vida normal e tranquila, do desastre prestes a assolar a 
Europa, uma vez surgir a ascensão do Partido Nacional socialista ao Poder na Alemanha, 1933, com consequência antissemita vestida de brutal violência, cuja resposta judaica foi fragmentada, incluso em círculos de otimismo político patético. A política cíclica nazista de isolar, discriminar e, finalmente, expulsar judeus se impunha gradativamente junto à propaganda hipócrita que mascarava ou distorcia seus efeitos. Mas uma petição das Leis Raciais à Liga das Nações, na ocasião, foi realizada na alta Silésia; todavia, essa resistência se torna excepcional e ignorada. Os próprios líderes nazistas se surpreenderam com a rapidez e facilidade em sua execução, no mérito da política antijudaica. A população não judaica, após longo período de doutrinação, aceitou a situação sem nenhuma refutação e manifestações antissemitas no Exterior foram inúteis. Assim, judeus aceitaram aos poucos o fato de que deveriam emigrar mesmo depois que as Leis de Nuremberg, 1935, os privaram da cidadania alemã. Em 1938, a emigração acelerou após a anexação da Áustria e dos Sudetos no mês de outubro; e depois dos pogroms, em 9 de novembro deste mesmo ano (Kristallnacht), quando em uma única noite foram queimadas centenas de sinagogas e cerca de 100 judeus assassinados, nas ruas. Entre os anos de 1933 e 1938, 150 mil judeus abandonam o país e igual número foge à invasão da Polônia. Perdidos quanto aos seus destinos não sabiam qual a rotina tomar em meio bélico e acusações fraudulentas e maldosas por parte dos que tinham o poder. Nessa jornada o surgimento de um surto: a peste negra oriunda da Ásia [época computada do conquistador Gênghis Khan e do profeta, médico, alquimista, médico e escritor Michel de Notredame, Nostradamus, que assistiu imponente a morte de sua mulher e filhos ocasionada pela peste negra] -, iniciada na Itália, Sicília. Absurdamente são acusados pela epidemia, servindo, inclusive, de roteiro a Giovanni Boccacio em sua obra Decameron. [Os poderosos logo se calaram após verificação de bactéria a ser tratada com simples antibiótico].

Entre 1941 e 1945, os nazistas exterminaram cerca de seis milhões de cidadãos judeus, um atlas de violência inaceitável, em cômputo mais triste em que se inclui inocentes crianças, cujos números falam por si. Não é apenas questão de números durante este cataclismo, de intensidade e brutalidade sem precedentes, o que não ameniza a rejeição de horror e desolação de um Povo que não tem culpa de ser o escolhido pelo Pai Todo-Poderoso. A estratégia de eliminá-los em guetos, campos de concentração e de extermínio é qualificada de absoluta barbárie, uma vez à volta de proscritos da sociedade e convertidos em bodes expiatórios de todos os males do Mundo. As mortes não serviram a nenhum objetivo político-militar concebível, a não ser o do ódio irracional, bestial, altamente doentio de certos instintos humanos, o que os levou a total destruição. Os sobreviventes se tornaram desorientados pela perda da cidadania, da família, dos lares e de todo o panorama de perspectiva de vida, porque não tinham para onde ir, uma vez britânicos limitarem a emigração estrita à Palestina, além do fechamento das portas das colônias fundadas naquela época. 
Após o Holocausto, sobreviventes tentam reivindicar saída estratégica rumo à Palestina, mas o Governo britânico se opôs a incrementar a imigração judaica, quando durante a guerra as condições existentes impediam, mediante justificativa baseada em argumento único: o da necessidade de se evitar que árabes se unissem ao Eixo geográfico. A situação havia se modificado, mas era evidente que o novo Governo trabalhista londrino manteria a política de seus predecessores, ou seja, o de cultivar a amizade dos árabes e, assim, frustrar objetivos sionistas. Esforços à introdução de refugiados clandestinos foram triplicados e diversas facções militares sionistas foram responsáveis pela coordenação de ações de sabotagem contra instalações militares britânicas. Em seguida, o Governo britânico se recusa a acatar a recomendação do Comitê de Pesquisa Anglo-Americano, em 1946, de transferir 100 mil refugiados judeus da Europa para a Palestina, acarretando crise internacional. Até a Agência Judaica, que antes se opôs à atividade terrorista e ter tentado colaborar com a Grã-Bretanha, adotou postura inédita de confronto com autoridades britânicas. Em agosto de 1917, o Comitê Especial das Nações Unidas sobre a Palestina recomendou a conclusiva do Mandato e a independência da Palestina; a maioria dos membros do Comitê resolve também a reposição do país em Estado judeu e outro em Estado árabe, subscrito pela Assembleia Geral das Nações Unidas, de 29 de setembro daquele ano. Os Estados árabes se opuseram à partição e o Governo britânico se recusa a efetivá-la. Premissa final: a iniciativa para os judeus de a Palestina estabelecer seu próprio Estado independente, o que aconteceu. E na tarde de 14 de maio de 1948 - data anunciada pelos britânicos para retirada -, o Conselho Nacional se reúne em Tel Aviv e promulga a Declaração de Independência!

\section{A Israel moderna}

Aindependência, datada em final de tarde de 14 de maio de 1948, foi aclamada mediante discórdia e desespero e tarde demais por não ter resguardado os seis milhões de mortos; amarga demais para a História da Humanidade. Não é nada fácil em termos de sensibilidade visitar Auschwitz, na Polônia, ou ao Museu Torre das Fotos, em Nova York. Os olhos são as janelas dos Espíritos encarnados; têm dupla função: a de enxergar e a do derramamento de lágrimas e é o que acontece quando se visita lugares assinalados. $\mathrm{O}$ mesmo sucede ao se debruçar os olhos na composição do enredo na leitura de O Diário de Anne Frank [abandonado em assoalho de sobrado, em estilo clássico holandês, textos de um diário foram encontrados pelo pai da menina Anne que viveu 2 anos escondida - no sótão daquela casa - junto aos pais e alguns conhecidos da perseguição aos judeus. $O$ diário se torna legado inconteste à História judaica pelo conteúdo; documento revertido à Literatura internacional e parâmetro às montagens de peças teatrais, exibidas em centros culturais de todo o Mundo, inclusive no Brasil, no final dos anos 60, em São 
Paulo no Teatro das Artes, anexo ao Teatro Brasileiro de Comédia (TBC), tendo no elenco Berta Zemel a primeira atriz judia-brasileira a desempenhar a história da jovem menina, protagonista desta obra-prima]. A defensoria protetora individual de Oskar Schindler a grupos desesperados judeus, versada em documentos comprobatórios, se reverte em obra prima da arte cinematográfica, cuja gratidão é contemplada no Museu "Avenida dos Justos", Jerusalém, por meio de pedra implantada em solo hebraico com o seu nome, entorno de outras de seus protagonistas protetores!

Mas a luta pela independência israelense ajudou a unir facções judias, uma vez lembrança traumática do Holocausto às profundezas da alma coletiva judaica triunfar em sua própria recompensa. Antissemitas foram silenciados e o novo Estado de Israel recebe apoio entusiástico de todas as partes judaicas do Mundo. Abolidas restrições à imigração, refugiados europeus começam a chegar seguidos pelos países árabes, cuja situação havia se tornado instável devido ao conflito do Oriente Médio. ${ }^{2}$

Em maio de 1949, o Estado de Israel foi admitido nas Nações Unidas, cuja bandeira nacional israelita é desenhada com o símbolo "Estrela de David" e considerada uma das mais belas do planeta. Por outro lado, judeus da antiga URSS continuaram vítimas do sistema soviético, dada imensa campanha contra o cosmopolitismo e o sionismo, e quando milhares deles tiveram destino antissocial: levados aos campos de trabalho forçado - alguns condenados à morte - após julgamento sumário. Este período ficou conhecido como Anos Negros, de 1948 a 1953. Nesse mesmo período, considerável grupo de judeus retorna à República Federativa alemã com o propósito de se estabelecer em reforço considerável de reconciliação. Em 1951, o chanceler alemão Adenauer, no Parlamento de Bonn, sublinhou a

obrigação de reparação moral e material pelos infindáveis crimes perpetuados em nome do povo alemão e anunciou que o Governo havia decidido a encontrar solução à compensação material que permitisse a expiação espiritual de inauditos sofrimentos.

Em 1952, celebra-se acordo com o Estado israelense e uma entidade judaica representativa pelo qual a Alemanha se comprometia a ressarcir em montante elevado

2 Esse conflito do Oriente Médio se estendeu do Iraque e toda Europa Oriental, porque os judeus nunca reconheceram uma autoridade espiritual única como o califa ou o papa. A coesão e a uniformidade das comunidades judaicas dispersas dependiam da adesão voluntária dos rabinos à disciplina da Thorah, de origem divina, e de contatos que mantinham entre si; todavia, essa coesão não era absoluta, quando a unidade comunal, às vezes, era perturbada por conflitos de caráter pessoal ou ideológico. Alguns movimentos sectários se estenderam para o Leste, sob a influência de tendência similar do Islã, advindo por meio de um deles, o caraísmo, significando desafio real e firme para a autoridade rabínica. Os caraítas mantinham suas próprias comunidades e com frequência junto às comunidades rabínicas. Depois de 1795, os nazistas fizeram uma guerra de extermínio contra eles na Crimeia e hesitavam em classificá-los como judeus. 
pecuniário à assistência e reabilitação dos sobreviventes - aos moldes de indenização - junto ao fomento de projetos culturais. Por meio da influência das Igrejas alemãs, centenas de jovens alemães viajam à Israel para trabalhar com os judeus: um gesto de arrependimento e reconciliação. Em 1967, o Egito respaldado pela URSS provoca novo confronto, acarretando a Guerra dos Seis Dias. Israel tem espetacular vitória, garantindolhe o controle da Jerusalém antiga e, ao mesmo tempo, ocupa novos territórios, multiplicando várias vezes sua área geográfica em maior tamanho. A vitória traz prestígio, alívio e júbilo ao Estado de Israel e abre espaço à renovação da propaganda antissemita na antiga URSS; assim como entre os intelectuais de linha esquerdista no Ocidente. Em 1970, um grupo de judeus de Leningrado tenta sequestrar uma aeronave no intuito de fuga para o Estado de Israel, cujo resultado negativo, levou-os à prisão e obrigados a trabalhos forçados. Pena tão severa que a maioria deles não resistiu. Em 1971, sob o lema bíblico "Deixai Sair o Meu Povo", aumenta consideravelmente a demanda pelo direito de emigrar, acolhida no Ocidente. Em surpresa entusiástica, os russos autorizam os vistos de saída em grande escala ao país da bandeira azul/branca desenhada com a "Estrela de Davi”. Em 1973, Israel enfrenta nova invasão árabe, desmoronando o clima de paz e confiança, desde 1967, e no ano seguinte, 1974, o líder da Organização para a Libertação da Palestina foi convidado a comparecer pela Assembleia Geral das Nações Unidas. Em 1975, a instituição adota por 72 votos contra 35 e 32 abstenções uma Resolução que equipara o sionismo a racismo; e esta adesão pública à propaganda antissionista contribuiu ao reanimo e ao apoio instintivo dos judeus ao Estado de Israel; ao mesmo tempo alguns sionistas iniciam manifestar simpatia pela causa palestina. Problemas continuaram, batizando a história mais recente do Estado israelense como as insurreições palestinas nos territórios ocupados, a Intifada.

Entre 1987 e 2000, ríspida resposta do Governo nacionalista radical de Ariel Sharon. Mas antes, o registro dos esforços de diferentes países ou de organismos internacionais para mediar o conflito, a saber: a Conferência Internacional de Paz do Oriente Médio de Madri, em 1991, na qual Israel participa pela primeira vez e a da assinatura de compromisso, em 2003. O objetivo era o do reconhecimento do Estado palestino, cujo acordo de paz - mediante permuta de territórios - dividiu opinião pública israelense, nos mesmos moldes do ocorrido com o acordo de Taba, 1995, rejeitado pelos colonos israelenses e palestinos. Por último, a continuidade de ação armada pelos palestinos levou Ariel Sharon à construção de um Muro de Segurança que, aliás, condenado pela opinião pública internacional e pelo Tribunal Penal Internacional de Haia, em 2004. Enfim, no século XXI, abre-se total etapa de incerteza caracterizada pelas disputas entre setores palestinos, após a morte de Yasser Arafat, além do surgimento de novo terrorismo islâmico internacional. 
Finalizando, é de conhecimento geral de que, após a Segunda Guerra Mundial, o Reino Unido não apoiou os judeus na fundação de sua pátria; todavia, a experiência do Holocausto modificou profundamente o caráter judeu, lembrando que depois da Primeira Guerra, a Palestina passa a ser controlada pelo Governo britânico. Por intermédio da Declaração Balfour, britânicos prometem auxílio ao Povo judeu no sentido de estabelecer a sua pátria, na Palestina, e foram taxativos: "jamais poderiam prejudicar palestinos árabes”! A Declaração Balfour incendeia o volátil ânimo dos palestinos, quando conflitos recomeçam e judeus, em minoria, se armaram fortemente; ao mesmo tempo, a Grã-Bretanha buscava, inutilmente, conciliação entre as duas partes.

Os judeus tentaram apoiar o Governo britânico, durante a ascensão do nazismo, mas perceberam que estavam por conta própria; e na inacreditável e impensável chacina promovida por Adolf Hitler, junto aos seus companheiros, enfatizando o oficial alemão Heinrich Himler, fez nascer o que Menachem Begin, líder da milícia judaica, Irgun, os chamassem de “os judeus combatentes”. E devido à imigração vetada à Palestina nem mesmo refugiados, sobreviventes aos campos de extermínio, puderam entrar no seu país. Cansados de esperar que as Nações estrangeiras interviessem a favor de sua causa e cientes da necessidade à construção de uma pátria judaica que pusesse término às históricas perseguições, os sionistas se voltam ao terrorismo, no intuito de fundar o seu país. E conseguiram!

\section{O Direito Talmúdico. O Direito Hebreu}

Talmude, do hebraico, significa ensinamentos; trata-se de compilação literária, escrita em hebraico e aramaico, reúne debates e discussões dos antigos rabinos acerca de vasta gama de questões. Os ensinamentos têm duas formas na observância jurídico-social: Talmude babilonico e Talmude Palestino. O Direito Talmúdico se tornou a pedra fundamental do Judaísmo rabínico e a sua autoridade sofreu ataques dos caraítas, cristãos e judeus reformados; todavia, ainda hoje, constitui a base das instruções na yeshivot, que por sua vez, se aproxima, também, ao conceito de Direito Consuetudinário, isto é, usos e costumes de determinado povo ou comunidade. Dentre alguns apontamentos régios deste diploma, a condenação. O Direito Talmúdico não admitia a condenação de um réu baseada em sua confissão, exigindo o testemunho de dois indivíduos: "que nenhuma decisão seja realizada sobre evidência apresentada apenas por uma testemunha", ensinamento rezado por Maimônides e, como tal, preceito que impede julgamentos divorciados do Princípio da Equidade, evitando riscos da tortura no Processo Penal. Os primeiros indícios de sistematização normativo-jurídica dos judeus da Antiguidade recaem ao período do domínio babilônico e uma série de circunstâncias é aventada à condução de os judeus elaborarem um Direito avançado para a sua época, notabilizado 
pela preocupação com a equidade - elemento psicológico desse Povo -, a crença e estudos; por isso classificado como Povo do Livro (a'm hasefer). Esse Povo do Oriente Médio, dedicado aos estudos e aos anos de reflexão elaborou normas de caráter ético, religioso e social, inseridas na Thorah, por meio de rolos com textos de perfil sagrado, enfatizando os especiais: o Shabat; acrescentam-se, ainda, interpretações hermenêuticas com conclusivas do Direito Talmúdico. Mais tarde, mediante recomposição do panorama político-social, são estruturadas normas jurídicas, observadas no conteúdo do Direito Talmúdico, as quais até hoje servem de parâmetro ao Estado de Israel, enfatizando a área do Direito de Família. Modernamente, o Estado de Israel não possui um Código Civil, tendo como parâmetro o Direito Talmúdico, apêndice do Direito hebreu.

E ao Direito hebreu são inseridos não só o Direito Talmúdico como a Thorah e ambos influenciaram ou aprimoraram outros ramos, dentre eles normas estritamente analisadas dos Direitos Humanos. Enfim, dentre as maiores virtudes do Judaísmo é a erudição que, por milhares de séculos, têm os rabinos, na função de estudantes e professores da Thorah, lembrando que eles anotavam, rigorosamente, resultados de trabalhos em comentários, resultando série de escritos eruditos, origem da Lei Oral que passou a ser intitulada Mishna (ensino), desenvolvida na época do Segundo Templo, período entre a volta do cativeiro da Babilônia, 515 a.C., e a diáspora, 70 d.C., uma vez no retorno à Judeia, os hebreus tiveram de se adaptar a novos meios de vida, porque o velho Direito bíblico não mais condizer ao modo-de-ser desse Povo especial. Premissa final: $o$ Direito hebreu é um Direito religioso.

\section{Conclusão}

Neste século XXI, o Judaísmo continua enfrentando polêmicas internas e constantes desafios, destacando-se como o mais significativo: a perda da Fé, motivado pelo Holocausto como, também, o distanciamento da vida tradicional, a partir das migrações mais recentes. Mesmo porque, esses traços vinculados ao crescimento do laicismo da sociedade moderna, em seu conjunto, levaram uma legião de judeus a questionar o significado e o valor da Religião. Existe determinado grupo entre judeus religiosos dúbios em relação à concepção tradicional de Jeová como, também, da vigência dos antigos códigos e a última formulação definitiva da halakhá ("regulamentação") ou parte da Religião e do pensamento judaico relativo às normas jurídicas elou éticas - programa ideal de vida judaica - que foi elaborado no século XVI, cuja primeira reação aconteceu após a expulsão dos judeus pelo Império espanhol. O grupo assinalado reivindica ser necessário realizar uma revisão à luz dos novos tempos O Judaísmo moderno se apresenta instável em parâmetro à homogeneidade do rabinismo talmúdico, incluso a possibilidade de se desenhar paralelismo com período muito anterior, ou seja, o dos últimos tempos 
do Segundo Templo, época do Rei Salomão, considerado o homem mais sábio entre todos os homens, nesta passagem terrena. As reminiscências ainda resistem ao tempo, mesmo porque alguns sobreviventes, verdadeiros heróis, estão conosco e relembram, ano passado, 2018, a Noite dos Cristais, fato acontecido na Alemanha e na Áustria, em 9 de novembro de 1938; 80 anos atrás, antes da Segunda Guerra Mundial. O episódio catastrófico, oriundo ao ódio de judeus, eliminou 97 cidadãos judeus e 30 mil aprisionados, 1,4 mil lojas comerciais de suas propriedades destruídas junto às sinagogas das mais belas edificadas àquela época.

As principais organizações religiosas tentam, atualmente, atrair os jovens judeus à Religião e não são raras as atrações em campanhas a converter gentios ao Judaísmo como, também, se estimula a conversão dos cônjuges não judeus em casamentos mistos, incluso a ala radical, os ortodoxos. Observa-se processo de secularização no âmbito das instituições religiosas, em período que as sinagogas desenham papel de centros culturais e sociais. O Judaísmo deve temer a secularização muito menos que o Cristianismo, porque as instituições judaicas se encontram muito mais espiritualizadas em parâmetro às cristãs. Os procedimentos religiosos, observância à Thorah, são a alma viva da Religião, enquanto as regras oficiais e doutrinas teológicas são totalmente secas e sem vida, a exemplo do Purim, ${ }^{3}$ cristalinamente popular e enorme abrangência, cuja celebração oficial consiste na leitura do Livro de Ester e nos donativos, no intuito da construção de obras de caridade. Os traços do Judaísmo não são compartilhados por nenhuma outra Religião, a exemplo da circuncisão e da restrição alimentar junto ao do calendário próprio - Shabat - que acontece aos sábados e durante sete dias não se trabalha; dedica-se o tempo às atividades agradáveis: frequências social e familiar. Esse comportamento nos leva aos ensinamentos do filósofo francês Maurice Hauriou em seu Compêndio de Direito Constitucional:

Cada parte do povo é um corpo social organizado, com seus objetivos, sua forma, sua especialidade, sua fisionomia. $\mathrm{O}$ povo é feito de famílias, comunidades, associações, uniões,

3 [Purim significa "os fados"; trata-se de festividade a comemorar a liberação dos judeus do Império persa, da conspiração genocida de Haman, conforme narração no "Livro de Ester"]. Outro evento religioso popular e clássico é o "tashlikh" no Ano Novo: os pecados são lançados na água ou o "kapparol”, em kippur: joga-se para o alto uma ave em sacrifício; todavia. Provoca desconforto em algumas comunidades. Mas neste século XXI esses hábitos cerimoniais não têm observância generalizada. Alguns costumes arraigados como as celebrações de "bar mitzvá", cerimônia de admissão de um rapaz à comunidade cultural adulta, ocorre aos 13 anos ou a Festa de Simchat Tora que marca o fim do ciclo anual de leitura da Thorah; devem sua origem a uma demanda popular. No Judaísmo oficial não há credulidade aos homens e mulheres santos de poderes sobrenaturais; mas, algumas comunidades reverenciam alguns santos em seus santuários e desempenham papel fundamental na vida religiosa, cuja tendência alcança o cabalismo, forte no Norte-africano e no Oriente Médio. [cabala, do hebraico, significa tradição; trata-se de sistema teosófico, atingindo apogeu de criatividade na Espanha, século XIII, em Safed - Zefat na Israel moderna - na Escola de Isaac Luria. Esotérica, a cabala exerceu considerável influência sobre o Cristianismo renascentista e o Judaísmo popular Norte-africano e do Iêmen]. 


\begin{abstract}
alianças, ligações, vinculações, congregações, institutos, corporações, sociedades, empresas, categorias profissionais, sindicatos, centrais, classes, quadros, grupos de pressão, frentes, partidos, federações, confederações, pactos, ligas, ordens, centros, círculos, prêmios, clubes, escolas, universidades, academias, igrejas, etc. E completa em seu "Compêndio", que o povo é mais feito de instituições do que de indivíduos isolados.
\end{abstract}

Assim como o Povo judeu é uma odisseia por séculos, o hebraico é um idioma eterno, porque no Período romano, quando deixou de ser idioma falado se transformou em língua erudita e litúrgica e nesta modalidade se difundiu por todo o Mundo como, também, continuou a ser empregada durante séculos, embora dificílima na assimilação ou aprendizagem, aos que não a conhece. E no momento em que parecia vencida, o Iluminismo hebraico a revive, em grande diversidade, desde a poesia lírica aos artigos científicos. Por fim, o ciclo se completa com a ressurreição do hebraico como língua falada e oficialização estatal no Estado de Israel. Completando, não há momento algum em que o hebraico não estivesse evoluindo e mesmo assim qualquer criança israelita podia ler e compreender a Bíblia hebraica sem a necessidade de preparação especial.

O moderno hebreu falante do hebraico, de comportamento consciente ou não, emprega constantemente palavras e frases encontradas nos estratos mais remotos do idioma, há cerca de 3 mil anos atrás; nomeia objetos e ideias das mais atuais e a Literatura hebreia moderna, rica e variada, recebe tanto influência recente da Europa quanto das tradições hebreias escritas, que remontam séculos e séculos. Segundo historiadores rabinos, no Pentateuco há exatamente 613 preceitos (248 mandamentos e 365 proibições); todo o material escrito por Moisés até 1225 a.C.; todavia, estudiosos creem que a Thorah contenha textos procedentes de diferentes séculos compilados entre 800-600 a.C. Nos últimos anos modernos, historiadores e jornalistas estudiosos do Judaísmo, atribuem função mais específica, quando afirmam que a repetição de letras, em intervalo, se trata de Código capaz de revelar mensagens ocultas, incluso o de predizer o futuro da Humanidade. As letras, Códigos da Thorah, yud, shin, resh, alef e lamed, compõem a palavra Israel, encontradas em intervalos de sete letras, no primeiro parágrafo da bênção do Kidush, recitadas em todas as noites das sextas-feiras ... e não se apresentam como coincidência nenhuma! Por último, o grupo judaico dos essênios, do qual Jesus de Nazaré pertenceu, 2 mil anos atrás, deixou legado documental imprescindível ao futuro da Humanidade em papiros dos Manuscritos da Guerra em consonância similar ao Livro das Revelações: historiadores, jornalistas, cientistas têm procurado decifrá-los, como o mais fiel e antigo documento interpretativo do Pentateuco, os primeiros Livros ditados por Deus a Moisés: o Códice de Aleppo e os Códices de Leningrado-de 1490 e o mais 
completo substituto ao de Aleppo - e o de Timóteo. São encontrados na Biblioteca do Museu Nacional de Jerusalém: a busca pelo conhecimento é a força que move o Mundo.

São Paulo, fevereiro de 2019.

\section{Referências}

ARMSTRONG, Karen. Em nome de Deus: o fundamentalismo no judaísmo, cristianismo e islamismo. Tradução Hildegard Feist. São Paulo: Companhia das Letras, 1998.

BARYLKO, Jaime. La filosofia de Maimónides. Buenos Aires: Marymar, 1985.

BLANC, Claudio. Um sistema de vida. In: BLANC, Claudio. História das religiões especial. São Paulo, Online, 2015. p. 64-73.

BRENNAN, Robert John; CORRÊA, David R. D. Profecias messiânicas. São Paulo: [s. n.], 1989.

CAHILL, Thomas. A dádiva dos judeus. Tradução de Ana Luiza Borges de Barros. São Paulo: Objetova, 1999.

CAMPOS NETO, Antonio Augusto Machado de. O judaísmo. O direito talmúdico. Revista da Faculdade de Direito da Universidade de São Paulo, São Paulo, v. 103, p. 27-67, jan./dez. 2008.

COHEN, Boaz. Law and tradition in Judaism. New York: Jewish Theological Seminary of America, 1966.

DE LANGE, Nicholas Robert Michael. Povo judeu: odisseia através dos séculos. Tradução de Carlos Nougué, Francisco Magalhães, Maria Júlia Braga e Joana Bergman. Barcelona: Folio, 2007.

FALK, Ze'ev W. O direito talmúdico. São Paulo: Perspectiva, 1988.

GUIMARÃES, Sabbá Isaac. O direito talmúdico como precursor de direitos humanos. Revista Jus Navigandi, Teresina, ano 10, n. 856, nov. 2005. Disponível em: https://jus.com.br/artigos/7470/odireito-talmudico-como-precursor-de-direitos-humanos.

JOHNSON, Paul. História dos judeus. Tradução de Carlos Alberto Pavanelli. Rio de Janeiro: Imago, 1989.

KAMEL, Ali. Sobre o Islã: a afinidade entre muçulmanos, judeus e cristãos e as origens do terrorismo. Rio de Janeiro: Nova Fronteira, 2007.

MACHADO, Antonio Claudio da Costa. O casamento no pentateuco. Revista da Faculdade de Direito da Universidade de São Paulo, São Paulo, v. 84/85, p. 27-34, jan./dez. 1989/1990.

MAIMÔNIDES, Moses. Comentários da Mishná: ética dos pais Sanhedrin. Tradução de Alice Frank. São Paulo: Maayanot, 1993. 
MAIMÔNIDES, Moses. Mishné Torá: o livro da sabedoria. Tradução Yaacov Israel Blumenfeld. Rio de Janeiro: Imago, 1992.

Os 613 mandamentos. Tradução de Giuseppe Nahaïssi. São Paulo: Nova Stella, 1999.

MAROTTA RANGEL, Vicente. Direitos humanos, judaísmo e ordem internacional. Revista da Faculdade de Direito da Universidade de São Paulo, São Paulo, v. 78, p. 234-240, jan./dez. 1983.

SACCO, Joe. Palestina: uma nação ocupada. Tradução de Cris Siqueira. São Paulo: Conrad, 2001.

WILKINSON, Philip. O livro ilustrado das religiões: o fascinante universo das crenças e doutrinas que acompanham o homem através dos tempos. São Paulo: Publifolha, 2002. 